\title{
The Influence of Health Workers' Knowledge, Attitudes and Compliance on Implementation of Standard Precautions in Hospital-Acquired Infections Prevention at X Hospital Bantul
}

\author{
Muhammad Ade Bagus Permana \\ Master of Hospital Management, \\ Universitas Muhammadiyah Yogyakarta, Yogyakarta, Indonesia \\ Nur Hidayah \\ Master of Hospital Management, \\ Universitas Muhammadiyah Yogyakarta, Yogyakarta, Indonesia
}

\begin{abstract}
Prevention of infection is a form of efforts to maintain patient safety in health services in hospitals. However, the large number of health workers with low knowledge, inappropriate attitudes and non-adherence in the implementation of standard precautions makes increase the number of infections acquired in hospitals. This was an observational analytic study with cross-sectional design. Knowing the knowledge, attitudes and compliance to 99 health workers consisting of nurses and midwives in the inpatient room, intensive care unit and delivery room of $X$ Hospital Bantul during July to August 2017. Data analysis using multiple logistic regression. There are three things that are assessed are knowledge, attitude and obedience. All aspects are assessed to have an effect on the application of standard precautions where compliance is the most influential factor in the application of standard precautions in the prevention of hospital-acquired infections.
\end{abstract}

Keywords: Knowledge; Attitude; Compliance; Standard Precautions; Hospital-Acquired Infections.

\section{INTRODUCTION}

In the era of globalization, good service is an important factor in the implementation of health services in hospitals. Hospitals are required to provide health services that meet optimal service standards in order to compete with other hospitals. Some developed countries change quality to quality-safety, this shows not only improved quality but patient safety is also important in the implementation of health services [1].

Health services are a place for interactions between patients and hospitals involving patients, doctors, nurses and other healthcare professionals in sensitive relationships related to satisfaction, quality of care and hospital image [2]. Hospitals are health care institutions that run individual health services in a plenary manner providing inpatient, outpatient, and emergency care services and its implementation based on Pancasila and based on human values, ethics, professionalism, benefits, equity, equality, anti-discrimination, protection, patient safety and social functions [3].

Prevention of infection is a form of efforts to maintain patient safety in health services in hospitals. Infections that occur more than 48 hours after admission to the hospital are called Hospital-Acquired Infections (HAIs) [4]. The World Health Organization (WHO) describes hospital-acquired infections as an infected patient during hospitalization that is absent or 
incubated at admission and exists after the patient is discharged from the hospital and the infection that a health worker obtains while working in the hospital [5].

The 2013 study in Europe was found to have a prevalence of hospital-acquired infections of $50 \%$, consisting of $29 \%$ wound infections, $26 \%$ gastrointestinal infections, $19 \%$ pneumonia, $16 \%$ urinary tract infection and $4 \%$ sepsis [6]. Figures nosocomial infections continue to increase to $9 \%$ or more than 1.4 million hospitalized patients in hospitals worldwide. Research conducted by Perdalin Jaya and Infectious Disease Hospital Prof. Dr. Sulianti Saroso Jakarta in 2003, from 11 hospitals in DKI Jakarta surveyed obtained nosocomial infection rate for infections wound surgery $18.9 \%$, urinary tract infection $15.1 \%$, primary blood flow infections $26.4 \%$, pneumonia $24.5 \%$ and other respiratory infections $15.1 \%$, and other infections $32.1 \%$ [7]. High incidence rates of hospital infections serve as an indicator of the quality of health services, therefore infection prevention measures nosocomial is very important for health personnel in hospital [8].

All levels of hospital management play an important role in the spread and control of infections, especially health workers. A health worker is any person who devotes himself to the health sector and has knowledge and skills through education in the field of health which for certain types requires authority to make health efforts [9]. Health workers play an important role in the prevention of infection, because health workers make direct contact with patients while providing health services so as to provide an opportunity to transmit infection to patients [10]. Health workers are often exposed to microorganisms, many of which can cause serious infections or even cause death [11].

The ability of health workers to prevent infections in hospitals is a major goal in the implementation of quality health services. In order to provide quality health services, health personnel must have the knowledge, skills and attitude necessary to meet the needs and care of nursing / medical treatment of patients in the hospital [12]. Therefore every action taken by health workers can prevent the occurrence of infection through vigilance and implementation of the correct procedure. Such precautions may be carried out by applying the standard precaution in nursing care / medical treatment to patients in the hospital. Standard precautions are basic precautions that should be applied in all patient care [13].

Hospital-acquired infections can be prevented by various measures, such as maintaining hand hygiene and the use of personal protective equipment. Hand hygiene is widely acknowledged as the most important activity to reduce the spread of disease, but evidence suggests that many health workers do not decontaminate hands as often as they need or use the correct technique [14]. Personal protective equipment is used to protect themselves and patients from the risk of cross-infection. Personal protective equipment includes items such as gloves, aprons, masks, eye protection, hats and footwear [13].

Research conducted in Korea on prevention of hospital-acquired infections showed 9.48\% of nurses did not wash their hands and use personal protective equipment. The study was conducted to assess the awareness, compliance, attitudes and self-efficacy of the nurses for the control of HAIs [15].

\section{RESEARCH METHODS}

This study was an observational analytic study with cross-sectional design conducted at $\mathrm{X}$ Hospital of Bantul, consisting of: inpatient room, intensive care unit and maternity room from July to August 2017. Sampling was done by random sampling through survey and 
questionnaire consisting of questions on 99 health workers consisting of nurses and midwives who perform health services at X Hospital of Bantul.

\section{RESULT AND DISCUSSION}

Characteristics of respondents viewed by age, gender, last education, occupation, length of work, marital status and employment status at X Hospital of Bantul.

Table 1. Characteristics of respondents

\begin{tabular}{|c|c|c|}
\hline Characteristic & Frequency & Percen (\%) \\
\hline \multicolumn{3}{|l|}{ Age } \\
\hline $20-25$ years old & 9 & 9,1 \\
\hline 26-30 years old & 19 & 19,2 \\
\hline $31-35$ years old & 36 & 36,4 \\
\hline $36-40$ years old & 24 & 24,2 \\
\hline $41-45$ years old & 11 & 11,1 \\
\hline \multicolumn{3}{|l|}{ Gender } \\
\hline Male & 12 & 12,1 \\
\hline Female & 87 & 87,9 \\
\hline \multicolumn{3}{|l|}{ Education Level } \\
\hline Associate's degree & 70 & 70,7 \\
\hline Bachelor's degree & 29 & 29,3 \\
\hline \multicolumn{3}{|l|}{ Type of Work } \\
\hline Nurse & 82 & 82,8 \\
\hline Midwife & 17 & 17,2 \\
\hline \multicolumn{3}{|l|}{ Period of Work } \\
\hline$<5$ years & 31 & 31,3 \\
\hline 5-10 years & 38 & 38,4 \\
\hline $10-15$ years & 19 & 19,2 \\
\hline $15-20$ years & 10 & 10,1 \\
\hline$>20$ years & 1 & 1,0 \\
\hline \multicolumn{3}{|l|}{ Marital Status } \\
\hline Married & 83 & 83,8 \\
\hline Unmarried & 16 & 16,2 \\
\hline \multicolumn{3}{|l|}{ Employment Status } \\
\hline Permanent & 75 & 75,8 \\
\hline Honorary & 13 & 13,1 \\
\hline Apprentice & 11 & 11,1 \\
\hline
\end{tabular}

At the age, it was seen that 9 respondents (9.1\%) were 20-25 years old, 19 respondents (19.2\%) were 26-30 years old, 36 respondents (36.4\%) were 31-35 years old, 24 respondents (24.2\%) aged 36-40 years and 11 respondents $(11.1 \%)$ of the total number of respondents aged 41-45 years. From the description, the largest number of respondents of this study came from the age group 31-35 years that is as many as 36 people or equivalent $36.4 \%$ of the total respondents.

In the gender, 12 respondents (12.1\%) were male and 87 respondents (87.9\%) were female. From the description, the largest number of respondents of this study were women.

At the education level, 70 respondents (70.7\%) have associate's degree education background 
and 29 respondents (29.3\%) with bachelor's degree education background. From the description, in this study the largest respondents came from the background of associate's degree education.

In the type of work, the number of respondents who have jobs as nurses are 82 respondents $(82.8 \%)$ and midwives of 17 respondents or $(17.2 \%)$. From the description, the nurse is the most types of work.

In the period of work, 31 respondents (31.3\%) had worked for less than 5 years, 38 respondents (38.4\%) had worked for 5 -10 years, 19 respondents $(19.2 \%)$ had worked for 10 15 years, 10 respondents $(10,1 \%)$ have been working for $15-20$ years and 1 respondent (1\%) have been working for more than 20 years. From the description, respondents in this study at most are health workers who have worked for 5-10 years.

In marital status, 83 respondents (83.8\%) were married and $16(16.2 \%)$ were unmarried. From the description, marriage status of health personnel under study is already married.

In the employment status, 75 respondents (75.8\%) were permanent employees, 13 respondents (13.1\%) were honorary employees and 11 respondents or $11.1 \%$ were apprentices. From these data employees remain the most employment status.

Table 2. Univariate analysis results

\begin{tabular}{lcc}
\hline Variable & Frequency & Percen (\%) \\
\hline $\begin{array}{c}\text { Knowledge } \\
\text { Poor }\end{array}$ & 59 & 59,6 \\
Good & 40 & 40,4 \\
Attitude & & \\
$\quad$ Negative & 76 & 76,8 \\
$\quad$ Positive & 23 & 23,2 \\
Compliance & & \\
$\quad$ Not Obey & 76 & 76,8 \\
$\quad$ Obey & 23 & 23,2 \\
Standard Precautions & & \\
$\quad$ Not good & 68 & 68,7 \\
Good & 31 & 31,3 \\
\hline
\end{tabular}

In knowledge, health workers at X Hospital have poor knowledge about 59 respondents $(59,6 \%)$ and 40 respondents $(40,4 \%)$ have good knowledge. This shows the knowledge of health workers on the application of standard precautions in the acquisition of hospitalacquired infections is lacking.

In attitudes, health workers in negative attitudes of 76 respondents or (76.8\%) and 23 respondents $(23.2 \%)$ had a positive attitude. This shows the attitude of health workers to the implementation of standard precautions in preventing hospital-acquired infections is lacking.

At compliance, health workers who have disobedient level of 76 respondents (76.8\%) and compliance rate of 23 respondents (23.2\%). This shows that the compliance of health workers with the application of standard precautions in preventing HAIs is lacking. 
In the standard precautions, 68 respondents (68.7\%) were not good in the application of standard precautions and 31 respondents (31.3\%) in the application of standard precautions. This shows the application of standard precautions by health workers in the prevention of hospital-acquired infections is lacking.

Table 3. Chi-Square test result

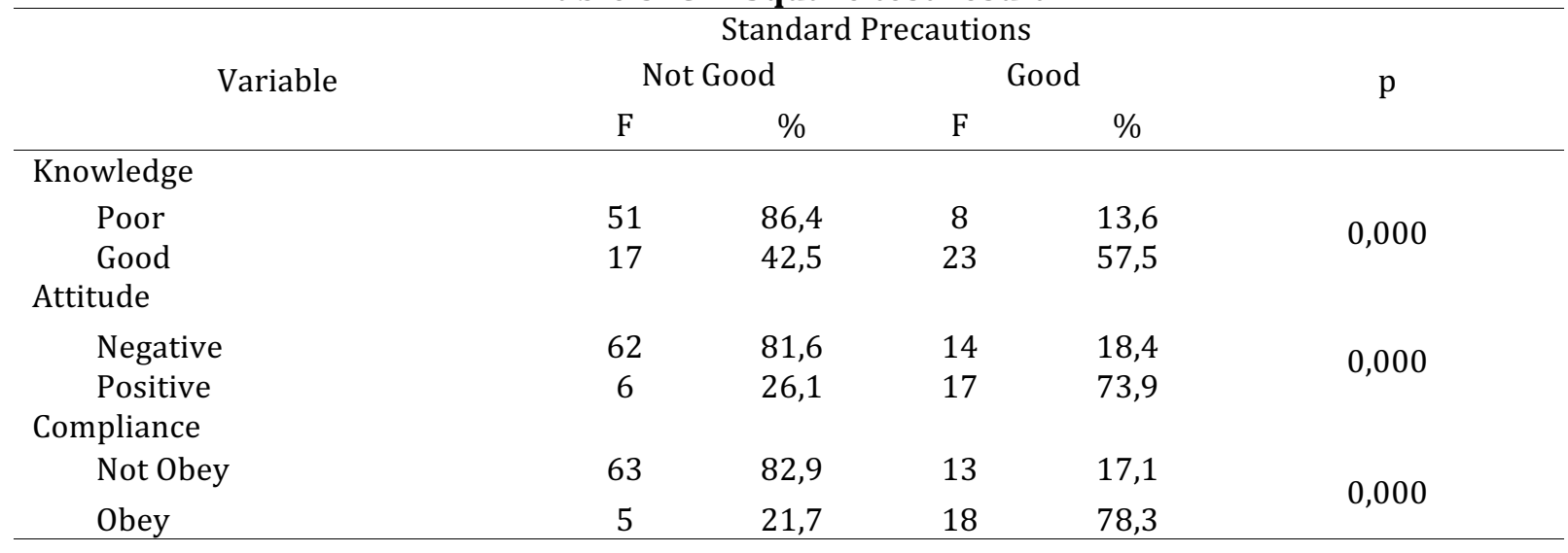

The knowledge shows that health workers with poor knowledge and poor standard precaution counted 51 respondents (86.4\%), while health workers with poor knowledge and good standard precaution application were 8 respondents $(13.6 \%)$. Health workers with good knowledge and poor standard precaution were 17 respondents $(42.5 \%)$, while health workers with good knowledge and good standard precaution were 23 respondents (57.5\%). From the results of fisher's exact test analysis of knowledge with the application of standard precaution obtained p value 0,000 , then there is a correlation between knowledge with the application of standard precaution.

In attitudes of health workers who have negative attitudes and poor standard precautions are 62 respondents (81.6\%), while health workers have negative attitude and good standard precaution application is 14 respondents (18.4\%). Health workers who have positive attitude and improper application of standard precaution are 6 respondents $(26.1 \%)$, while health workers have positive attitude and good standard precaution application is 17 respondents $(73,9 \%)$. From the results of fisher's exact test analysis between attitudes with the application of standard precaution obtained p value 0,000 , then there is a correlation between attitude with the application of standard precaution.

The compliance showed that health workers were not compliant and the application of poor standard precaution was 63 respondents (82.9\%), while the non-adherent health worker and the application of good standard precaution were 13 respondents (17.1\%). Adequate health workers and poor implementation of standard precaution were 5 respondents $(21.7 \%)$, while obedient health personnel and good standard precaution were 18 respondents $(78.3 \%)$. From the results of fisher's exact test analysis between compliance with the implementation of standard precaution obtained $\mathrm{p}$ value 0,000 , then there is a correlation between compliance with the application of standard precaution.

Table 4. Multiple Logistic Regression test result

\begin{tabular}{lccc}
\hline Variable & $\mathrm{p}$ & OR & Nagelkerke \\
\hline Knowledge & 0,037 & 3,409 & \\
Attitude & 0,016 & 5,041 & 0,472 \\
Compliance & 0,017 & 5,349 & \\
\hline
\end{tabular}

Multivariate analysis in this study using multiple logistic regression test with $\mathrm{p}$ value $<0.25$, 
this research all variables have an influence on the application of standard precautions. Compliance is the most influential variable in the application of standard precautions, with a $\mathrm{p}$ value of 0.017 and an OR value of 5,349 which means obedient health personnel tend to apply standard precautions 5,349 times than non-adherent health workers. Attitudes become the second influencing variable after compliance in the application of standard precautions, with $\mathrm{p}$ value 0.016 and OR 5,041 which means health workers with positive attitude tend to apply standard precautions 5,041 times than health workers who have negative attitude. Knowledge becomes the third influencing variable after compliance and attitudes in the application of standard precautions, with $\mathrm{p}$ value 0.037 and OR value of 3,409 which means that health workers with good knowledge tend to apply standard precautions 3,409 times compared to health workers who do not have good knowledge.

From Nagelkerke analysis it is known that the percentage of all variables is $47.2 \%$, which means knowledge, attitude, and compliance can affect the application of standard precautions of $47.2 \%$. While $52.8 \%$ comes from other factors that are not ditelti by researchers.

\section{Influence Knowledge of Implementation of Standard Precautions in Prevention of Hospital-Acquired Infections}

The knowledge shows that health workers with poor knowledge and poor standard precaution counted 51 respondents (86.4\%), while health workers with poor knowledge and good standard precaution application were 8 respondents $(13.6 \%)$. Health workers with good knowledge and poor standard precaution were 17 respondents (42.5\%), while health workers with good knowledge and good standard precaution were 23 respondents (57.5\%). From the results of fisher's exact test analysis of knowledge with the application of standard precaution obtained p value 0,000 , then there is a correlation between knowledge with the application of standard precaution.

Some health workers at X Hospital have good knowledge. Good knowledge of health workers influences the application of standard precautions. In additions there are other factors, research entitled Gambaran Pengetahuan Perawat Tentang Kewaspadaan Standar di RSUD Raden Mattaher Jambi explained there are other factors that can affect compliance, such as education and employment. High education and long service life can influence the knowledge of health personnel in the implementation of standard precautions [16]. In this study, health workers at X Hospital have associate's degree and bachelor's degree education with the most working period is $5-10$ years, namely $38.4 \%$ of total research respondents.

The knowledge of health workers on the application of standard precautions is also influenced by the availability of information about standard precaution which includes the availability of references or information and the accessibility of previous journals or research on standard precaution. Knowledge influences the application of standard precaution, a person with good knowledge tends to apply standard precautions in the hospital [17]. The study also explains the role of educational institutions to teach the principle of standard precaution that can provide knowledge about the applicability of standard precautions that can be applied at work. Increased knowledge of health workers on the implementation of standard precaution to prevent HAIs can be done by conducting training for health workers. Most health workers who are not trained in the prevention of hospital-acquired infections have low knowledge in infection prevention. Training is useful for improving the knowledge of health personnel in practice while working [18]. 
According to the results of the study, researchers can conclude the existence of the relationship between knowledge with the implementation of standard precaution caused by some health workers still have less knowledge in the application of standard precaution. Knowledge and skills on standard precaution can be enhanced through regular training to better the knowledge of health workers and prevent hospital-acquired infections.

\section{Influence of Attitudes toward Implementation of Standard Precautions in Hospital- Acquired Infections Prevention}

In attitudes of health workers who have negative attitudes and poor standard precautions are 62 respondents (81.6\%), while health workers have negative attitude and good standard precaution application is 14 respondents (18.4\%). Health workers who have positive attitude and improper application of standard precaution are 6 respondents (26.1\%), while health workers have positive attitude and good standard precaution application is 17 respondents $(73,9 \%)$. From the results of fisher's exact test analysis between attitudes with the application of standard precaution obtained p value 0,000 , then there is a correlation between attitude with the application of standard precaution.

A person's attitude is a precipitating factor for the formation of an action against a particular object. Attitude is a reaction or response to a stimulus or object and is an emotional reaction to social stimulus. Attitude is not an act or activity but it can affect action or behavior [19].

In this research there are some health workers have a negative attitude toward the implementation of standard precaution. Negative attitude of health workers in X Hospital of Bantul is influenced by the habit that formed in hospital environment. The negative attitude of health personnel is also influenced by the lack of reference in the implementation of standard precaution and the lack of facilities provided by the hospital so that the implementation of standard precaution is not in accordance with the recommended procedure. Implementation of inappropriate precaution standards has become one of the risks of spreading infection in hospitals.

In this study there are some health workers who are negative do not apply standard precautions. Attitudes relate to the application of standard precautions consisting of the application of hand hygiene and the use of personal protective devices [20]. A person with a negative attitude is less likely to implement standard precautions and a person with a positive attitude tends to apply standard precautions in serving patients.

There is a correlation between attitude and the application of standard precautions. Negative attitudes of respondents are due to a limitation in interaction with patients and their application procedures that take time [21]. However, in this study, most health professionals said they did not feel the use of personal protective equipment limited the interaction and application of hand hygiene did not take much time.

According to the results of the study, researchers can conclude an increase in attitude is very necessary health workers to prevent the spread of hospital-acquired infections. Increasing attitudes of health workers can be done by getting used to apply standard precautions in health services in hospitals. Usually the implementation of standard precautions can be realized if a good cooperation is established from the hospital with health workers in the form of providing facilities and supervision of the hospital so that health workers always apply standard precautions. 


\section{Effect of Compliance with the Application of Standard Precautions in Prevention of Hospital-Acquired Infections}

The compliance showed that health workers were not compliant and the application of poor standard precaution was 63 respondents (82.9\%), while the non-adherent health worker and the application of good standard precaution were 13 respondents (17.1\%). Adequate health workers and poor implementation of standard precaution were 5 respondents $(21.7 \%)$, while obedient health personnel and good standard precaution were 18 respondents (78.3\%). From the results of fisher's exact test analysis between compliance with the implementation of standard precaution obtained $p$ value 0,000 , then there is a correlation between compliance with the application of standard precaution.

Non-compliance in the application of standard precautions can be caused by many factors. The drive for a person to take precautions depends on a health belief that is perceived threat of injury or illness and consideration of benefits and cost. The perceived threat of injury or illness refers to the extent to which a person thinks illness is a threat that will adversely affect him, if the perceived threat increases then prevention behavior will increase as well [22]. Health workers who feel themselves at risk and are easily infected more likely to comply with standard precautions guidelines or procedures [23].

Occupational safety factors are another factor that can affect compliance. Occupational safety hospitals have health workers 2.9 times more adherence to run standard precautions and health workers who are trained in standard precautions 5.7 times more compliant in practice [24].

Lack of time is the cause of non-compliance [25]. In order for better time management, training on time management for health workers is required. The training aims to help individuals become aware and aware of how to use the time organized and can make priority in their implementation. With time management, work can be done effectively and efficiently with the results of work obtained will be more qualified.

According to the results of the study, researchers can conclude the compliance of health workers in the hospital due to lack of continuous and ongoing training and lack of awareness of individuals to always apply standard precautions in health services.

\section{CONCLUSION}

Based on the results of the study and discussion, it can be concluded that knowledge, attitude and compliance have a significant influence on the implementation of standard precautions, where compliance is the most influential factor in preventing hospital-acquired infections in $\mathrm{X}$ Hospital of Bantul.

\section{References}

Kementerian Kesehatan RI. (2006). Pedoman Penyelenggaraan Keselamatan Pasien di Rumah Sakit. Jakarta: Departemen Kesehatan RI.

Suryawati, C., Dharminto, \& Shaluhiyah, Z. (2006). Penyusunan Indikator Kepuasan Pasien Rawat Inap Rumah Sakit di Provinsi Jawa Tengah. Jurnal Manajemen Pelayanan Kesehatan, 9(4), 177-184. https://doi.org/10.9774/jmk.13.1.61-75

Undang-Undang Republik Indonesia. (2009). Undang-Undang Republik Indonesia Nomor 44 Tahun 2009 Tentang Rumah Sakit. Jakarta: Undang-Undang Dasar Negara Republik Indonesia Tahun 1945.

Ocran, I., \& Tagoe, D. N. A. (2014). Knowledge and Attitude of Healthcare Workers and Patients on Healthcare Associated Infections in a Regional Hospital in Ghana. Asian Pacific Journal of Tropical Disease, 4(2), $135-139$. https://doi.org/10.1016/S2222-1808(14)60330-3 
WHO. (2011). The Burden of Health Care-Associated Infection Worldwide: A Summary. World Health Organization, 3. Retrieved from http://www.who.int/gpsc/country_work/summary_20100430_en.pdf

Ott, E., Saathoff, S., Graf, K., Schwab, F., \& Chaberny, I. F. (2013). The Prevalence of Nosocomial and Community Acquired Infections in a University Hospital. Deutsches Arzteblatt International, 110(31-32), 533-540. https://doi.org/10.3238/arztebl.2013.0533

Departemen Kesehatan RI. (2008). Pedoman Pencegahan dan Pengendlian Infeksi di Rumah Sakit dan Fasilitas Pelayanan Kesehatan Lainnya. https://doi.org/10.1017/CB09781107415324.004

Septiari, B. B. (2012). Infeksi Nosokomial. Yogyakarta: Nuha Medika.

Kemenkes. (2009). Undang-undang Republik Indonesia No. 36 Tahun 2009 Tentang Kesehatan. Undang-Undang Republik Indonesia, 1-48. https://doi.org/10.1017/CB09781107415324.004

Ghadamgahi, F., Zighaimat, F., Ebadi, A., \& Houshmand, A. (2011). Knowledge, Attitude and Self-Efficacy of Nursing Staffs in Hospital Infections Control. Journal of Military Medicine, 13(3), 167-172.

Efstathiou, G., Papastavrou, E., Raftopoulos, V., \& Merkouris, A. (2011). Factors Influencing Nurses' Compliance with Standard Precautions in Order to Avoid Occupational Exposure to Microorganisms: A Focus Group Study. BMC Nursing, 10(1), 1. https://doi.org/10.1186/1472-695 5-10-1

Hamid, A. Y. (2008). Buku Ajar Riset Keperawatan: Konsep, Etika, Instrumentasi Ed 2. Jakarta: Penerbit Buku Kedokteran EGC.

WHO. (2006). Standard Precautions in Health Care Key Elements at a Glance. World Health Organization, 1-2.

Butvidas, E. A. (2005). Good Practice in Infection Prevention and Control: Guidance for Nursing Staff. Royal College of Nursing, 20. Retrieved from http://www.wales.nhs.uk/sites3/Documents/739/RCNinfectioncontrol.doc.pdf

Kang, J., Cho, J., Kim, Y., Kim, D. H., Lee, J., Park, H. K., Lee, E. N. (2009). Hospital Nurses' Knowledge and Compliance on Multidrug-Resistant Organism Infection Control Guideline. Journal of Korean Academy of Nursing, 39(2), 186197. https://doi.org/http://dx.doi.org/10.4040/jkan.2009.39.2.186

Fahmi, I. (2012). Gambaran Pengetahuan Perawat Tentang Kewaspadaan Standart. Universitas Indonesia.

Earl, C. E. (2010). Thai Nursing Students' Knowledge and Health Beliefs about AIDS and use of Universal Precautions: a Cross-Sectional Descriptive Research Study. AAOHN Journal: Official Journal of the American Association of Occupational Health Nurses, 58(8), 331-334. https://doi.org/10.3928/08910162-20100716-01

Habni, Y. (2009). Perilaku Perawat Dalam Pencegahan Infeksi Nosokomial di Ruang Rindu A, Rindu B, ICU, IGD, Rawat Jalan di Rumah Sakit Umum Pusat Haji Adam Malik Medan. USU Repository. Universitas Sumatera Utara.

Wahid, I. (2007). Promosi Kesehatan. Yogyakarta: Graha Ilmu.

Maja, T. M. M., \& Motshudi, M. J. (2009). Precautions used by Occupational Health Nursing Students during Clinical Placements. Curationis, 32(1), 14-9. Retrieved from http://www.ncbi.nlm.nih.gov/pubmed/20225748

Anupam, K., \& Taneja, D. K. (2010). Health Care Workers and Universal Precautions: Perceptions and Determinants of Non-Compliance. Indian Journal of Community Medicine, 35(4), 526-528. https://doi.org/10.4103/ 0970-0218.74373

Machfoedz \& Eko. (2007). Pendidikan Kesehatan Bagian dari Promosi Kesehatan Masyarakat. Yogyakarta: Fitramaya.

Henderson, D. K. (2001). Raising the Bar: The Need for Standardizing the Use of "Standard Precautions" as a Primary Intervention to Prevent Occupational Exposures to Bloodborne Pathogens. Infection Control and Hospital Epidemiology, 22(2), 70-72. https://doi.org/10.1086/501866

McGovern, P. M., Vesley, D., Kochevar, L., Gershon, R. R. M., Rhame, F. S., \& Anderson, E. (2000). Factors Affecting Universal Precautions Compliance. Journal of Business and Psychology, 15(1), 149-161.

https://doi.org/10.1023/A:1007727104284

Sahara, A. (2011). Faktor-faktor yang Berhubungan dengan Kepatuhan Perawat dalam Penerapan Kewaspadaan Universal/Kewaspadaan Standar di Rumah Sakit Palang Merah Indonesia Bogor Tahun 2011. Universitas Indonesia. 